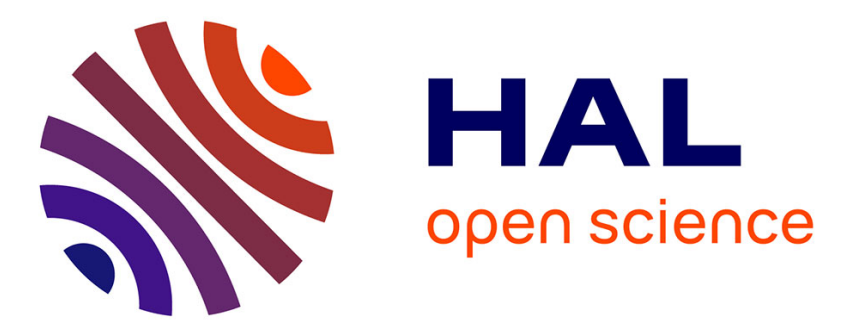

\title{
Electromagnetic Mapping of Pasargadae (Fars Province, Iran): Feedback from the 2017-2018 Fieldwork
}

\author{
Christelle Sanchez, Sébastien Gondet, Kourosh Mohammadkhani, Julien
}

Thiesson

\section{- To cite this version:}

Christelle Sanchez, Sébastien Gondet, Kourosh Mohammadkhani, Julien Thiesson. Electromagnetic Mapping of Pasargadae (Fars Province, Iran): Feedback from the 2017-2018 Fieldwork. Archeosciences, revue d'Archéométrie, 2021, 45, pp.115-118. 10.4000/archeosciences.8909 . halshs03510812

\section{HAL Id: halshs-03510812 \\ https://shs.hal.science/halshs-03510812}

Submitted on 5 Jan 2022

HAL is a multi-disciplinary open access archive for the deposit and dissemination of scientific research documents, whether they are published or not. The documents may come from teaching and research institutions in France or abroad, or from public or private research centers.
L'archive ouverte pluridisciplinaire HAL, est destinée au dépôt et à la diffusion de documents scientifiques de niveau recherche, publiés ou non, émanant des établissements d'enseignement et de recherche français ou étrangers, des laboratoires publics ou privés. 


\title{
Electromagnetic Mapping of Pasargadae (Fars Province, Iran): Feedback from the 2017-2018 Fieldwork
}

\author{
Christelle Sanchez ${ }^{a}$, Sébastien Gondet ${ }^{a}$, Kourosh Mohammadkhani ${ }^{\mathrm{b}}$ \\ and Julien Thiesson ${ }^{c}$
}

Highlights:

- Recent geophysical data on the large Achaemenid center of Pasargadae in South Iran.

- New data on the layout and geomorphology of the site.

- Feedback focusing on the implementation of two GF Instruments CMD electromagnetic devices.

Keywords: Iran, Pasargadae, electromagnetic, CMD instruments, feedback.

\section{INTRODUCTION AND FRAMEWORK}

\section{Archaeological background} and previous magnetic survey

An Iranian-French project, implemented since 1999 in collaboration with the Iranian Ministry of Cultural Heritage, has undertaken surveys to define the layout of the site of Pasargadae, the first Achaemenid royal centre founded around $550 \mathrm{BC}$ in ancient Persia (Fars province, South Iran), around the excavated monumental buildings. The basis is an integrative approach consisting of a combination of geophysical, UAV, fieldwalking, and geoarchaeological surveys. The collected data suggest that the Achaemenids created at Pasargadae a new landscape covering several hundred hectares. The open layout of the royal centre apparently integrated all the known buildings and settled areas within a large park and cultivated areas. Consequently, mapping Pasargadae means first and foremost mapping landscape features over large areas, for which purpose geophysics have been applied extensively ever since the start of the project.

The magnetic method was routinely implemented on about 120 ha, using a G858 Geometric magnetometer in gradiometer configuration. The results revealed a large rectangular drainage network of ditches integrating the Royal Area and its central Royal Garden that is outlined by a network of stone channels (Benech et al., 2012). Nearby, the survey also revealed a large 1.5 ha trapezoidal basin with sides built of stone. Further in the plain, several Achaemenid settled areas were also recognized (Gondet et al., 2019).

\section{Recent electromagnetic (EM) survey}

The magnetic map served to plan complementary noninvasive surveys in targeted areas at Pasargadae. The ones which show evidence of strong destruction by farming activities or erosion were mapped with an additional EM survey using GF Instruments CMD meters, carried out in

\footnotetext{
a Université de Lyon, CNRS, UMR 5133 Archéorient, Maison de l'Orient et de la Méditerranée, Lyon, France

${ }^{b}$ Department of Archaeology, Faculty of Letters and Human Sciences, Shahid Beheshti University, Tehran

Sorbonne Université, UMR 7619 METIS, Paris, France
} 


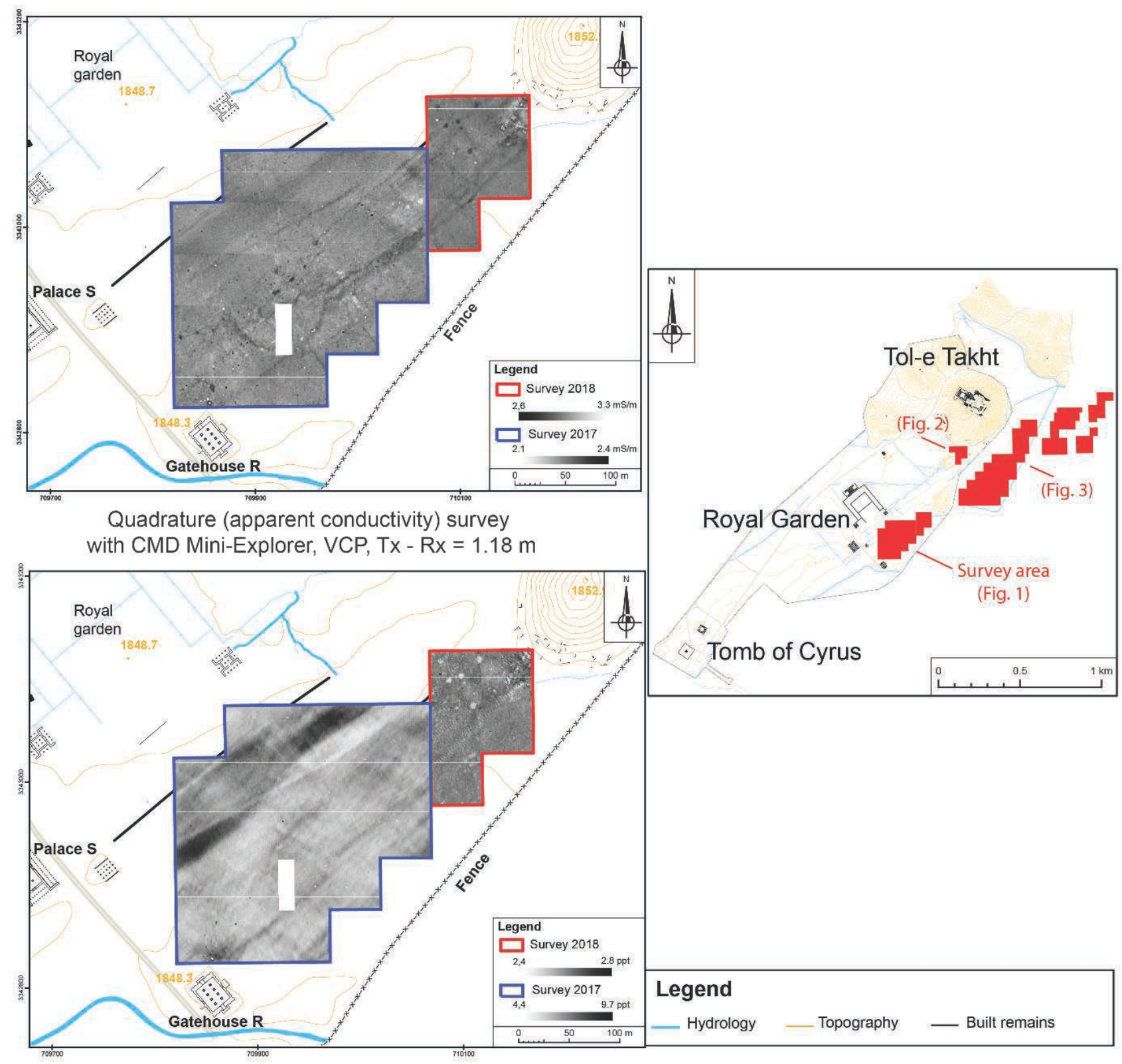

In-phase (apparent magnetic susceptibility) survey with CMD Mini-Explorer, VCP, Tx - Rx $=0.71 \mathrm{~m}$

Figure 1. CMD Mini-Explorer survey south-east of the basin: apparent conductivity map (on the top left) and in-phase/apparent magnetic susceptibility map (on the bottom left); location map of the surveyed areas (on the right).

2017 and 2018. Evaluation of the EM survey method at Pasargadae, based on these results, constituted one of the tasks of the French-German ANR-DFG "Paradise" project (grant number: ANR-16-FRAL-0011-01), started in 2017, focusing on a comparative landscape study of Achaemenid centres in South Iran and the Lesser Caucasus.
The CMD Mini-Explorer was used on 10 ha, following a fine-mesh data collection strategy (1-m profile spacing) with twofold objectives. In areas where modern ploughing had dismantled settlement remains, leaving a more magnetic trace of more or less unidentifiable shape and extent, the Mini-Explorer was tested to see whether the results could 


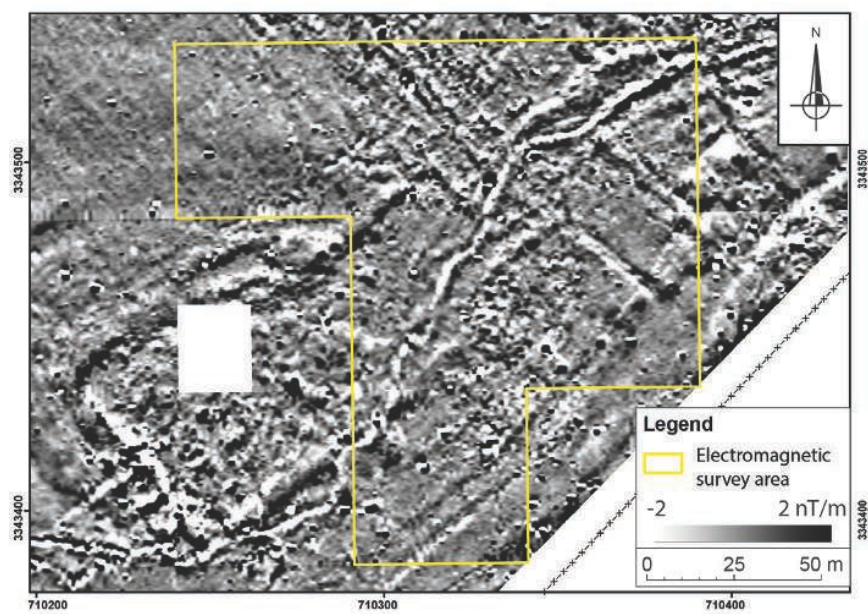

Magnetic field, pseudo-gradient with G858 magnetometer

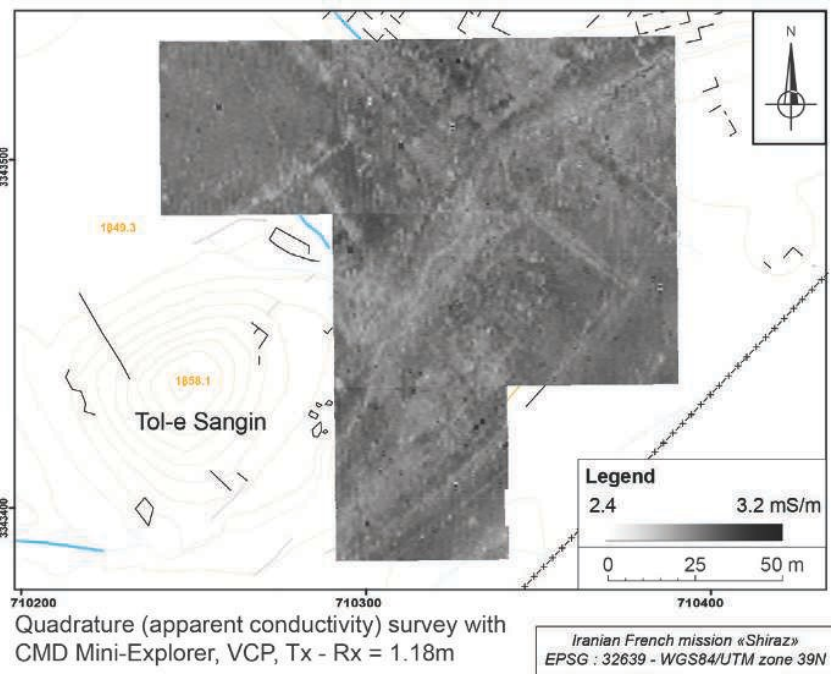

Figure 2. CMD Mini-Explorer survey near the Tol-e Takht hill: pseudo-gradient magnetic field map (on the left) and apparent conductivity map (on the right).

enhance mapping of more continuous anomalies, that is, amorphous magnetic areas, through in-phase measurements. The second objective was to reveal discrete anomalies linked to archaeological features potentially still preserved under the ploughed subsoil layer through the multi-depth conductivity measurement.

The CMD Explorer was used on 16.6 ha with a widemesh data collection strategy (5-m profile spacing) mainly outside of the protected site. The magnetic map has demonstrated that the site was affected by geomorphic processes in the past. Several flooding palaeochannels, connected to a river located several kilometres east of Pasargadae, can be observed across the site. The CMD Explorer mapped the in-depth conductivity on a large scale for bringing out the network of flooding channels upstream from the site. This has also tested the capacity of the instrument for outlining potential ancient settlement areas.

\section{OVERVIEW OF THE EM SURVEYS}

\section{EM CMD Mini-Explorer survey south-east of the Royal Garden: effects of meteorological conditions}

The EM survey, carried out in both seasons, aimed at better characterizing the ancient plot system and the settled area detected by the magnetic survey. The soil conditions of the survey were different: much dryer in 2017 than in 2018 (wetter after rainy events). Very low dynamics of conductivity measurements is observed in both instances. The conductive anomalies shown by the 2017 survey appea- red as resistive anomalies in the 2018 surveys (corrected by inverting the colour scale of the 2018 map on Fig. 1). A possible explanation is that material with coarser constituents and a larger porosity is less conductive in dry conditions; water filling the voids in this material resulted in a reversed conductivity-anomaly signature. The detected anomalies correspond to a modern irrigation channel network that had gone previously untraced on the magnetic maps. Useful in-phase datasets for both years were obtained only for the intermediate coil spacing. The presence of a trapezoidal basin to the north-west has been confirmed. However, other parts of the mapped area showed a low contrast. The difference in the range of in-phase values between the 2018 and 2017 surveys has yet to be fully understood.

EM CMD Mini-Explorer survey at the foot of the Tol-e Takht hill: shallow building remains revealed in heterogeneous subsoil

The conductivity map obtained in 2018 of the area between the Tol-e Sangin hill and the southern foot of the Tol-e Takht hill revealed many archaeological features that the noisy signal on the magnetic map had clouded from view (Fig. 2). This result from the magnetometry is caused by the presence of several superimposed layers, as well as colluvial material from the nearby slopes, that has made the soil very heterogeneous. The conductivity map shows a hydrological network in the surface layer and dense masonry structures at shallow depth inside a rectangular area delineated by a double line anomaly, probably a protective wall. 
Figure 3. CMD Explorer survey upstream from the Pasargadae Royal Area: apparent conductivity map ( 1 = palaeochannels, 2 = conductive $/$ settled area).

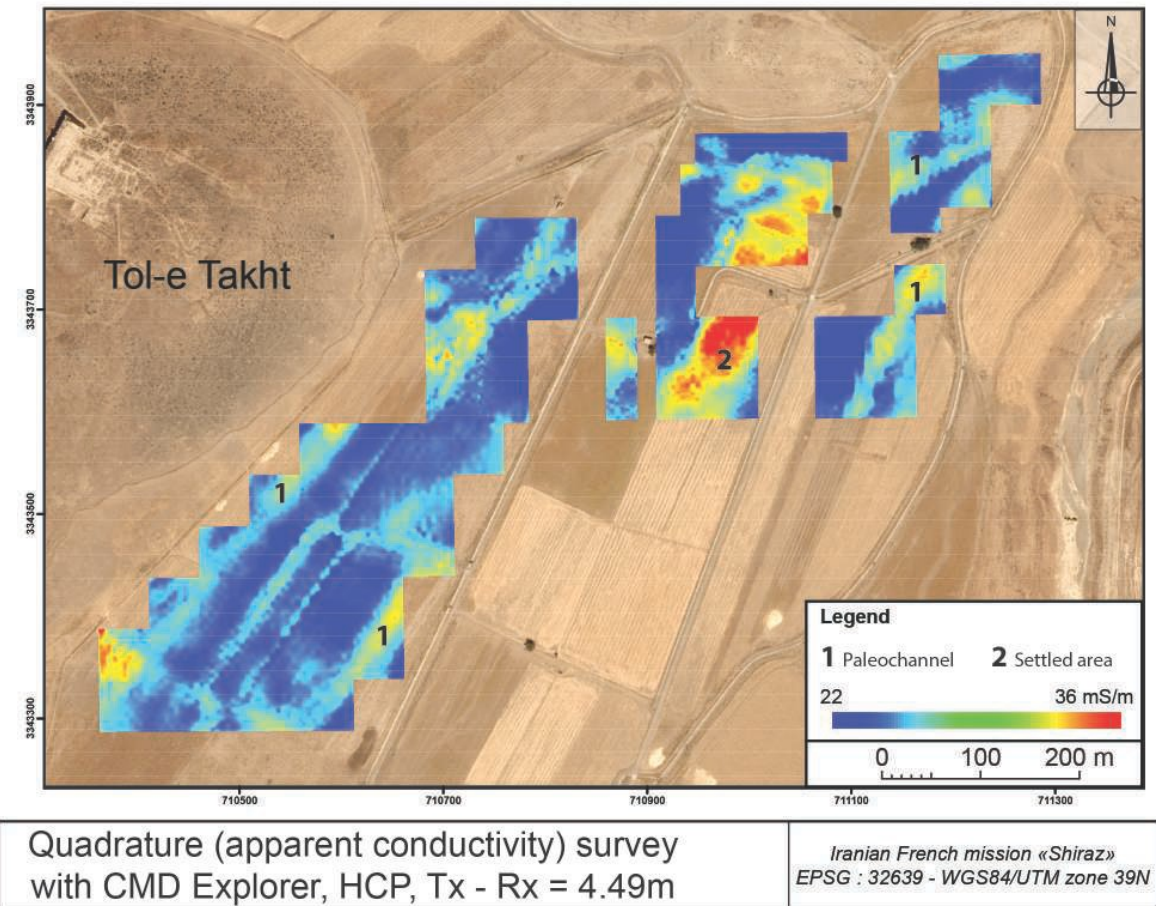

metry results. The EM survey with the longer CMD device appears to be more reliable. To complete these studies, other kinds of electromagnetic devices, MS2 and SM30, were used over stratigraphic sections in trenches opened during the 2018 geomorphological surveys. The results are still being processed, but it is expected that an in-depth analysis of soil properties will be possible in combination with the sedimentary analysis, thus complementing data from the mapping. In the future, data from the cultivated fields east of the protected site will help to carry out complementary surveys in selected locations, e.g., a magnetic survey of the allegedly settled areas. In addition, the geophysical results will constitute grounds for a continued program of soundings at Pasargadae started in 2019.

\section{References}

Benech, C., Boucharlat, R., Gondet, S., 2012. Organisation et aménagement de l'espace à Pasargades - Reconnaissances archéologiques de surface, 2003-2008. Arta, 2012.003: 1-38, http://www.achemenet.com/document/2012.003-Benech_ Boucharlat_Gondet.pdf

Gondet, S., Mohammadkhani, K., Djamali, M., Farjamirad, M., Gopnik, H., Ibnoerrida, N., Laisney, D., Notter-Truxa, F., Rigot, J.-B., Ubelmann, Y., 2019. Field report on the 2016 archaeological project of the Iran-French project on Pasargadae and its surrounding territory. Iranian Heritage Studies, 1(2): 1-22. 